\title{
NEW NAMES FOR TWO GENERA OF CARBONIFEROUS CORALS.
}

SIR,--Dr. H. Dighton Thomas, of the British Museum (Natural History), kindly brought to my attention the fact that the names of two new genera of corals established by me in my paper: "Faune du calcaire carbonifère du bassin houiller de Kousnetzk," ${ }^{1}$ have been pre-occupied. These are: Stylophyllum gen. n., ${ }^{2}$ a name already used by A. E. Reuss ${ }^{3}$ in 1854, and Craterophyllum gen. n., ${ }^{4}$ used by Aug. F. Foerste in 1909.5

I wish now to replace the first name by the new generic name Stelechophyllum (from the Greek word $\sigma \tau \epsilon \dot{\lambda} \in \chi \mathrm{O}_{\mathrm{S}}$, a trunk or $\log$ ), and offer the generic name Cypellophyllum (from the Greek word $\kappa v i \pi \epsilon \lambda$,, a beaker or cup) for Craterophyllum mihi.

In his letter, Dr. H. Dighton Thomas suggested also that it would be desirable if I should designate genolectotypes for the four new genera of corals created by me in the paper under consideration. New genera Peetzia ${ }^{6}$ and Cypellophyllum (=Craterophyllum Tolmachoff) are monotypic, with Peetzia minor Tolm. ${ }^{7}$ and Cypellophyllum abyssum (Tolm.) (=Craterophyllum abyssum Tolm.) ${ }^{8}$ as respective genotypes. Genolectotype of the new genus Stelechophyllum (= Stylophyllum Tolm.) is Stelechophyllum venukoffi (Tolm.) (= Stylophyllum venukoffi Tolm.), ${ }^{9}$ and that of the genus Disophyllum ${ }^{10}$ is Disophyllum symmetricum (Tolm.). ${ }^{11}$

\section{P. Tolmachoff.}

1 The paper was published by the Russian Geological Committee in two parts: Part i, in 1924, in Matériaux pour la Géologie Générale et Appliquée, livr. 25; part ii, in 1931, as a special publication. As a matter of fact, the first part was printed in 1914, but its continuation was interrupted by the Great War, Russian Revolution, and by the author leaving Russia. The author wishes to use this opportunity for expression of his deep and sincere gratitude to his friends in Russia, A. P. Karpinski, member and President of the Russian Academy of Sciences, and G. N. Fredericks, member of the Russian Geological Committee, who have been chiefly responsible for the appearance of this paper. Without the great authority of the former and the persistent efforts of the second even the first already printed part of the paper would probably never have appeared before the scientific world.

2 Op. cit., 316 and 606.

3 A. E. Reuss, "Beiträge zur Charakteristik der Kreideschichten in den Ostalpen, besonders im Gosauthale und am Wolfgangsee" : Denkschr. d. K. Akad. d. Wiss., Math.-Naturw. Cl., vii, 132, Wien, 1854.

4 Op. cit., 344 and 614 .

5 A. F. Foerste, "Fossils from the Silurian Formations of Tennessee, Indiana, and Illinois" : Bull. Sci. Lab. Denison Lniversity, xiv, 101, Granville, Ohio, 1909.

6 Op. cit., 309 and 603 .

8 Ibid., 345 and 614 .

10 Ibid., 341 and 613 .

7 Ibid., 312 and 604 .

9 Ihid., 318 and 607.

11 Ibid., 342 and 613 . 